\title{
Clinical Genetics Board Certification
}

National Cancer Institute

\section{Source}

National Cancer Institute. Clinical Genetics Board Certification. NCI Thesaurus. Code C18197.

The process by which a person is tested and approved to practice in the specialty field of clinical genetics. 